\title{
PURIFICATION AND PARTIAL CHARACTERIZATION OF LIVER CATALASE FROM CONTROL AND Pb+Cd METAL MIXTURE STRESSED Oreochromis niloticus
}

\author{
Tanveer Ahmed ${ }^{1, *}$, Sajid Abdullah', Khalid Abbas', Muhammad Anjum Zia ${ }^{2}$, Nadia Nazish', \\ Syed Zakir Hussain Shah ${ }^{1}$ and Syed Muhammad Aun Naqvi ${ }^{3}$
}

\author{
${ }^{1}$ Department of Zoology, Wildlife and Fisheries, University of Agriculture, Faisalabad, Pakistan; ${ }^{2}$ Department of \\ Biochemistry, University of Agriculture, Faisalabad, Pakistan; ${ }^{3}$ Department of Zoology, Govt. Postgraduate College, \\ Gojra, Pakistan. \\ "Corresponding author's e-mail: tanvirahmeduaf@gmail.com
}

\begin{abstract}
Water contamination is a severe environmental issue and has worse effects on fish health. Antioxidant system is present in all living organisms that maintain redox homeostasis by neutralizing reactive oxygen species (ROS). Catalase (CAT) is the part of antioxidant system that protect an organism from oxidative stress by detoxifying $\mathrm{H}_{2} \mathrm{O}_{2}$ into $\mathrm{H}_{2} \mathrm{O}$ and $\mathrm{O}_{2}$ molecule. Majority of enzymes are intermingled with other biomolecules when extracted and needed to purify so that biochemical properties can be described clearly. The first purpose of the present research work was to investigate whether tilapia produce more CAT in the chronic metal mixture stressed condition or not. While, the second purpose of the present research work was to purify and partially characterize the liver $\mathrm{CAT}$ from control and $\mathrm{Pb}+\mathrm{Cd}$ metal mixture stressed Oreochromis niloticus. The inferences of present study showed higher liver CAT activity in control $O$. niloticus as compared to binary metal mixture treated $O$. niloticus. Significant differences $(p<0.05)$ were observed when compared liver CAT activity among control and stressed fish. Specific activity of purified liver CAT was observed 1027.52 and $946.93 \mathrm{Umg}^{-1}$ for control and metal stressed fish, respectively. The fold purification of control and metal treated fish liver CAT was recorded 15.27 and 15.44, respectively. Optimum pH and temperature of liver CAT purified from both control and metal stressed fish was found 7 and $25^{\circ} \mathrm{C}$. Km value for control and metal stressed O. niloticus liver was measured 6.82 and $1.71 \mathrm{mM} \mathrm{H}_{2} \mathrm{O}_{2} \mathrm{~mL}^{-1}$, respectively. On the basis of present study inferences, it is concluded that chronic $\mathrm{Pb}+\mathrm{Cd}$ metal mixture stress condition did not improve the yield of liver CAT but inhibited in $O$. niloticus.
\end{abstract}

Keywords: Antioxidant enzyme, isolation, immunology, hepatocyte catalase, heavy metal treated, Nile Tilapia.

Abbreviations: CAT: Catalase, $\mathrm{H}_{2} \mathrm{O}_{2}$ : Hydrogen peroxide; ROS: Reactive oxygen species; SDS-PAGE: Sodium Dodecyl Sulphate Poly acrylamide gel electrophoresis; DEAE: Diethyl amino ethyl.

\section{INTRODUCTION}

Catalase (EC 1.11.1.6) is an oxidoreductase tetramer enzymes having $240 \mathrm{KDa}$ molecular weight approximately (Chagas $e t$ al., 2009) and contain four equally sized subunits that comprises one ferric prosthetic group and primarily found in peroxisomes (Chance et al., 1979). It acts as a catalyst in the breakdown of hydrogen peroxide $\left(\mathrm{H}_{2} \mathrm{O}_{2}\right)$ to oxygen $\left(\mathrm{O}_{2}\right)$ and water $\left(\mathrm{H}_{2} \mathrm{O}\right)$ molecules and give defense against the lethal effects of radicals produced due to oxygen (Dawson, 1988).

Reactive oxygen species (ROS) including hydroxyl radicals, hydrogen peroxide and superoxide anions are produced in less number during normal physiological conditions in an organism (Valko et al., 2006) that detoxify easily. However, when ROS production is higher than control level, it results in oxidative stress. ROS have a number of damaging effects to biomolecules such as DNA, lipids peroxidation in cell membrane, protein oxidation, sulfhydryls depletion and apoptosis (Stohs and Bagchi, 1995).
Liver is chosen for the study of oxidative stress due to its responsibility for body metabolic regulation and xenobiotics detoxification (Radovanovic et al., 2010).

Lead $(\mathrm{Pb})$ is the major heavy metal that causes environmental pollution (Sevcikova et al., 2011) and persist for longer time in aquatic environment. Different sources of lead pollution are paint, medicines, cosmetics, food supplements and petroleum based fuels (Stohs and Bagchi, 1995).

Cadmium $(\mathrm{Cd})$ is a metal that have no biological importance in living organisms (Liu et al., 2007) and found with zinc in the ores. It discharged in the environment as a result of mining and smelting of zinc. It is used in electroplating, batteries and galvanizing in different industries. It finds its way into aquatic environment through application of phosphate fertilizers, weathering of rocks, refining and mining of ores (Stohs and Bagchi, 1995).

Cadmium as pro-oxidants is one of the reasons of antioxidant system alteration (Almeida et al., 2009) that does not produce ROS directly. It influence thiol status of cell by altering 
glutathione S-transferase level and also accelerates the level of metallothioneins in the liver. Both of these changes become the reason of lipid peroxidation of plasma membrane. Cadmium then enters into mitochondrial electron transport chain and began to accumulate here. It donates electrons and results in superoxide radical production (Sevcikova et al., 2011).

Catalase is extensively use in the textile, agriculture and food industries now a days, thus commercial production of the catalase has a great value and promising future. However, till now, most of the catalase production came from the rodents and other mammals which make the cost of producing of the enzyme too high to afford. Isolating and purification catalase from Oreochromis niloticus provides a new thought which may reduce the cost of production and make the use of fish excreta in valuable products.

\section{MATERIALS AND METHODS}

Experimental animal: Fingerlings of freshwater fish, Oreochromis niloticus, commonly known as Tilapia were selected as an experimental animal and purchased from the Govt. Fish Seed Hatchery, Faisalabad, Pakistan and transferred live to the Fisheries Research Farms at University of Agriculture, Faisalabad, Pakistan. Fingerlings were acclimatized to laboratory conditions for two weeks.

Experimental trial: For experimental trial, two separate glass aquaria (one for control and one for metal mixture stress) were selected. After acclimatization, total 30 fish fingerlings were shifted randomly into selected glass aquaria (15 fingerlings in each aquarium). Various physico-chemical parameters were maintained at optimum level throughout the study period of 14 days. The fish fingerlings were fed with standard fish feed twice a day and $12 \mathrm{hr}$ light and $12 \mathrm{hr}$ dark photoperiod was maintained during the experimental trial.

Physico-chemistry for experimental animal: The physicochemical parameters viz. temperature, $\mathrm{pH}$, dissolved oxygen, total hardness, total alkalinity, carbonates and bicarbonates were determined on daily basis throughout study period by following the methods described in A.P.H.A (1998).

Chronic $\boldsymbol{P b}+\boldsymbol{C d}$ metal mixture toxicity to $O$. niloticus: $\mathrm{LC}_{50}$ value for $O$. niloticus was measured $55 \mathrm{mgL}^{-1}$ that was divided by 3 for obtaining chronic or sub lethal value. Pure compounds of lead chloride $\left(\mathrm{PbCl}_{2}\right)$ and cadmium chloride $\left(\mathrm{CdCl}_{2}\right)$ were dissolved in deionized water and stock solution (1000 ppm) was prepared in a jar.

$\mathrm{Pb}+\mathrm{Cd}$ metal mixture chronic toxicity stress was given to $O$. niloticus fingerlings at optimum water temperature, $\mathrm{pH}$, dissolved oxygen and total hardness for two weeks. From stock solution mentioned above, $183.4 \mathrm{~mL} \mathrm{~Pb}+\mathrm{Cd}$ metal mixture solution was introduced in the aquarium having fingerlings of $O$. niloticus for metal stress. The total quantity of solution was added in 6 hour duration so that fish fingerlings did not die (Naz et al., 2008).
After two weeks experimental trial, the fishes were dissected and liver was extracted from both control and $\mathrm{Pb}+\mathrm{Cd}$ metal mixture stressed $O$. niloticus and stored for further analyses at $-20^{\circ} \mathrm{C}$.

CAT enzyme assay: The activity of CAT was determined by measuring its ability to decompose $\mathrm{H}_{2} \mathrm{O}_{2}$ at $240 \mathrm{~nm}$ by following the methods of Chance and Mehaly (1977) with some modifications. A $50 \mathrm{mM}$ phosphate buffer $(\mathrm{pH} 7.0)$ and $10 \mathrm{mM}$ hydrogen peroxide $\left(\mathrm{H}_{2} \mathrm{O}_{2}\right)$ were prepared to make buffer substrate solution. The reaction mixture $(2 \mathrm{~mL})$ contained $1.95 \mathrm{~mL}$ buffered substrate solution and $0.05 \mathrm{~mL}$ enzymes extract. The buffer substrate solution was used as blank.

Estimation of protein contents: Biuret method of Gornall et al. (1949) was used for the estimation of protein contents with the help of DC Protein Assay Kit (Bio-Rad Laboratories, USA) by using BSA (bovine serum albumin) as standard.

Purification of liver CAT: Purification of liver CAT was performed by using the methods of Nakamura et al. (2000) with some modifications. All purification steps were carried out at $4{ }^{\circ} \mathrm{C}$. The liver of fish from both control and metal mixture stressed was weighted and phosphate buffer $(10 \mathrm{mM}$; $\mathrm{pH} 7.4) 4$ times greater than the weight of organ was added to it. It was homogenize for 15 minutes with the help of a homogenizer, filtered and centrifuged at 10, $000 \mathrm{rpm}$ for 15 minutes. Both sediments and supernatants were separated for further analyses.

Partial purification of liver CAT by ammonium sulfate precipitations: Crude extract of enzyme (100 mL) was saturated with $25 \%$ ammonium sulfate by dissolving $17.5 \mathrm{~g}$ Ammonium sulfate. After 6 hours incubation, it was centrifuged at $13,000 \mathrm{rpm}$ for 15 minutes at $4^{\circ} \mathrm{C}$. The supernatant that was obtained from salting in procedure was subjected to salting out method by adjusting the saturation upto $50 \%$. It was incubated at $4^{\circ} \mathrm{C}$ for 24 hours and then centrifuged at $13,000 \mathrm{rpm}$ for 15 minutes at $4^{\circ} \mathrm{C}$. Residues obtained from salting out were re-suspended and subjected to desalting with the help of dialysis bag in phosphate buffer (1.5 $\mathrm{mM} ; \mathrm{pH}$ 7.4) by following the methods of Nakamura et al. (2000).

Purification of liver CAT by ion exchange chromatography: The column of DEAE-cellulose (diethyl amino ethylcellulose) was prepared $(1 \times 20 \mathrm{~cm})$ for the purification of liver CAT. Slurry was prepared and an amount of $250 \mu \mathrm{L}$ desalted sample was applied on column. The sample was eluted out with the help of $10 \mathrm{mM}$ phosphate buffer ( $\mathrm{pH} 7.4$ ) while the drop rate was kept constant $(1 \mathrm{~mL} / \mathrm{min})$. A total of 50 fractions with $2 \mathrm{~mL}$ of elution were collected. Noted the optical density of all the fractions at $280 \mathrm{~nm}$ against blank (buffer). Fractions having higher absorbance were selected for enzyme assay and protein content estimation.

Purification of liver CAT by gel filtration chromatography: Column $(1 \times 20 \mathrm{~cm})$ of sephadex G-150 was prepared by following the methods of Umbreen et al. (2014) in phosphate 
buffer (10 mM; pH 7.0). An amount of $250 \mu \mathrm{L}$ of sample (with highest specific activity after ion exchange chromatography) was applied and 50 fractions with $2 \mathrm{~mL}$ were collected. Fractions showing higher absorbance were selected for enzyme assay and protein content estimation.

Partial characterization of purified liver CAT

Determination of optimum $\mathrm{pH}$, temperature and buffer concentration: Optimum $\mathrm{pH}$, temperature and buffer concentration was determined by assaying the purified CAT from both control and $\mathrm{Pb}+\mathrm{Cd}$ metal mixture stressed $O$. niloticus liver by following the methods of Nakamura et al. (2000) and Al-Bar (2012).

Statistical analysis: Data obtained in this study was analyzed by following appropriate methods of Steel et al. (1997). Experimental data was presented as Mean Standard Deviation (Mean \pm SD). One-way ANOVA was used to compare variables among both metal stressed and control fish at $p<0.05$.

\section{RESULTS}

The inferences of present study showed higher CAT activity (146.16 $\pm 0.165 \mathrm{UmL}^{-1}$ ) in the control O. niloticus liver (Table 1) as compared to metal stressed fish $\left(129.33 \pm 0.33 \mathrm{UmL}^{-1}\right)$.

Purification of CAT from control and $\mathrm{Pb}+\mathrm{Cd}$ metal mixture stressed $O$. niloticus liver: Statistical analysis revealed significant difference between control and metal treated $O$. niloticus regarding liver CAT specific activity (Fig. 1).

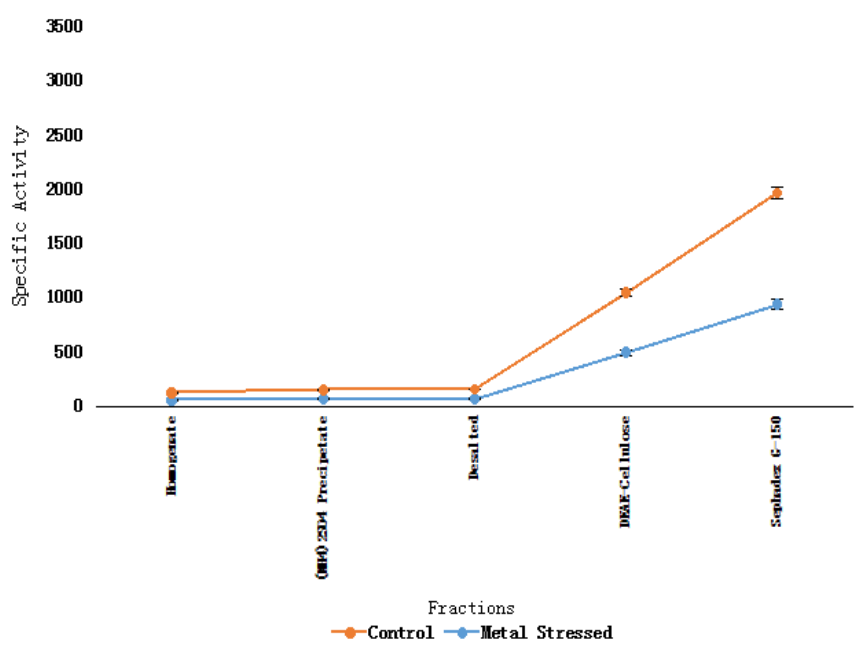

Figure 1. Specific activity curve from homogenate (before purification) to Sephadex G-150 (after purification).

Highest specific activity both from control and metal treated fish was noted 1027.52 and $946.93 \mathrm{Umg}^{-1}$, respectively. Inferences also indicated that the yield of enzyme decreases

Table 1. Activity of CAT enzyme from control and metal mixture stressed $O$. niloticus liver.

\begin{tabular}{|c|c|c|}
\hline Treatments & Fractions & Activity $\left(\mathrm{UmL}^{-1}\right)$ \\
\hline \multirow{6}{*}{ Control O. niloticus } & Crude Extract & $146.16 \pm 0.165^{a}$ \\
\hline & Salting in Supernatants & $105.00 \pm 0.000^{c}$ \\
\hline & Salting in Residues & $92.66 \pm 0.000^{\mathrm{e}}$ \\
\hline & Salting out Supernatants & $87.33 \pm 0.333^{\mathrm{fg}}$ \\
\hline & Salting out Residues & $79.33 \pm 0.333^{\mathbf{i}}$ \\
\hline & Desalted/Dialysis & $75.33 \pm 0.333^{\mathrm{k}}$ \\
\hline \multirow{6}{*}{ Stressed $O$. niloticus } & Crude Extract & $129.33 \pm 0.333^{\mathbf{b}}$ \\
\hline & Salting in Supernatants & $94.00 \pm 0.000^{\mathrm{de}}$ \\
\hline & Salting in Residues & $86.00 \pm 0.000^{\mathbf{f}}$ \\
\hline & Salting out Supernatants & $78.66 \pm 0.000^{\mathbf{h}}$ \\
\hline & Salting out Residues & $72.16 \pm 0.165^{\mathbf{j}}$ \\
\hline & Desalted/Dialysis & $63.66 \pm 0.000^{1}$ \\
\hline
\end{tabular}

The superscript notations ${ }^{\text {a,b,c,d,e,f }}$ indicate significant differences among Control and metal stressed O. niloticus

Table 2. Purification of control and $\mathrm{Pb}+\mathrm{Cd}$ metal mixture stressed $O$. niloticus liver $\mathrm{CAT}$.

\begin{tabular}{lcccrcr}
\hline \multirow{2}{*}{ Step } & \multicolumn{2}{c}{ Control O. niloticus } & \multicolumn{3}{c}{ Metal stressed O. niloticus } \\
\cline { 2 - 7 } & $\begin{array}{c}\text { Specific Activity } \\
\text { (U/mg) }\end{array}$ & $\begin{array}{c}\text { Yield } \\
(\boldsymbol{\%})\end{array}$ & $\begin{array}{c}\text { Enrichment } \\
\text { (fold) }\end{array}$ & $\begin{array}{c}\text { Specific Activity } \\
\text { (U/mg) }\end{array}$ & $\begin{array}{c}\text { Yield } \\
(\%)\end{array}$ & $\begin{array}{c}\text { Enrichment } \\
\text { (fold) }\end{array}$ \\
\hline Homogenate & 67.27 & 100.00 & 1.00 & 62.47 & 100.00 & 1.00 \\
$\left(\mathrm{NH}_{4}\right)_{2} \mathrm{SO}_{4}$ Precipitation & 85.30 & 54.09 & 1.26 & 71.28 & 55.79 & 1.14 \\
Desalted & 87.59 & 51.36 & 1.30 & 74.50 & 49.22 & 1.19 \\
DEAE-Cellulose & 553.48 & 41.13 & 8.22 & 501.52 & 42.26 & 8.02 \\
Sephadex G-150 & 1027.52 & 38.18 & 15.27 & 946.93 & 36.59 & 15.44 \\
\hline
\end{tabular}


gradually after each and every purification step and specific enzyme enrichment or fold purification increases after each step of purification (Table 2).

Comparison of purified liver CAT partial characterization from control and metal treated $O$. niloticus:

In Table 3, comparative partial characterization of purified CAT both from control and metal mixture stressed $O$. niloticus liver is shown. The inferences of purified CAT characterization when statistically analyzed on the basis of activity at $P \leq 0.05$, significant differences were observed.

Table 3. Comparison of purified liver CAT characterrization from control and metal stressed $O$. niloticus.

\begin{tabular}{lcc}
\hline Parameters & $\begin{array}{c}\text { Control } \\
\text { liver CAT }\end{array}$ & $\begin{array}{c}\text { Metal treated } \\
\text { liver CAT }\end{array}$ \\
\hline Specific activity $\left(\mathrm{Umg}^{-1}\right)$ & 1027.52 & 946.93 \\
Optimum pH & 7.0 & 7.0 \\
Optimum temperature $\left({ }^{\circ} \mathrm{C}\right)$ & 25 & 25 \\
Optimum phosphate buffer $(\mathrm{mM})$ & 50 & 50 \\
$\mathrm{Km}\left(\mathrm{mM} \mathrm{H}_{2} \mathrm{O}_{2} \mathrm{~mL}^{-1}\right)$ & 6.82 & 1.71 \\
Vmax $\left(\mathrm{mM} \mathrm{H}_{2} \mathrm{O}_{2} \mathrm{~mL}^{-1}\right)$ & 1.53 & 3.89 \\
\hline
\end{tabular}

Determination of optimum $\mathrm{pH}$ for purified liver CAT: Optimum $\mathrm{pH}$ of purified liver CAT both from metal mixture stressed and control O. niloticus was measured 7 (Fig. 2).

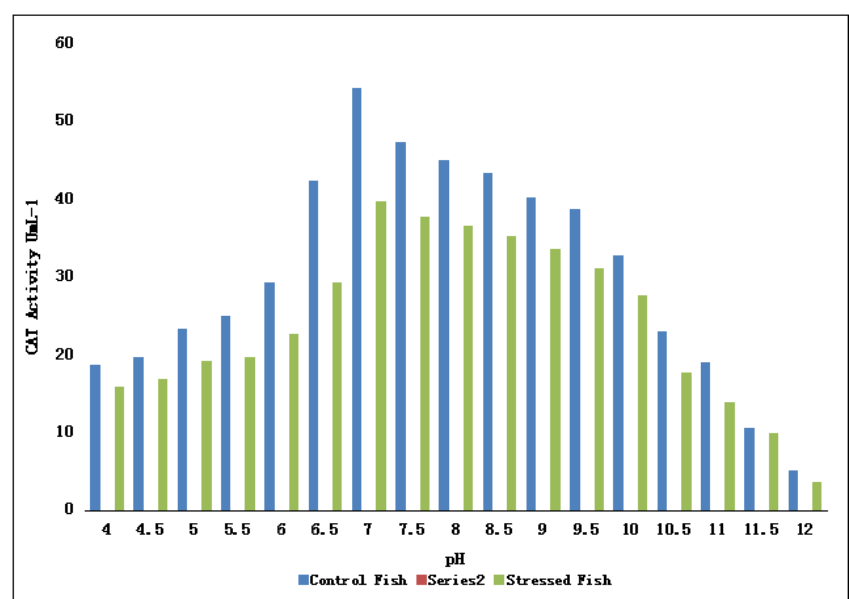

Figure 2. Measuring the optimum $\mathrm{pH}$ for $O$. niloticus liver CAT.

Determination of optimum temperature for purified liver CAT: Temperature at which purified liver CAT both from control and $\mathrm{Pb}+\mathrm{Cd}$ metal mixture stressed $O$. niloticus showed highest activity was observed $25^{\circ} \mathrm{C}$ although purified catalase showed broad range activity at different temperature (Fig. 3).

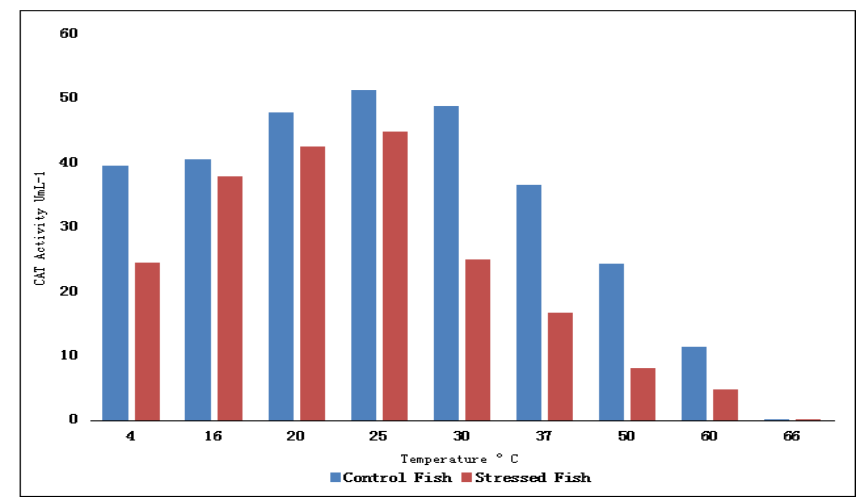

Figure 3. Measurement of optimum temperature for liver CAT of $O$. niloticus.

Determining $\mathrm{Km}$ and Vmax value for purified $\mathrm{O}$. niloticus liver CAT: Vmax value was measured about $1.53 \mathrm{U} \mathrm{mL}^{-1}$ and $3.89 \mathrm{U} \mathrm{mL}^{-1}$ for control and $\mathrm{Pb}+\mathrm{Cd}$ metal mixture stressed purified liver CAT, respectively (Fig. 4 and 5). Low value of Vmax indicates CAT stronger ability to bind with $\mathrm{H}_{2} \mathrm{O}_{2}$.

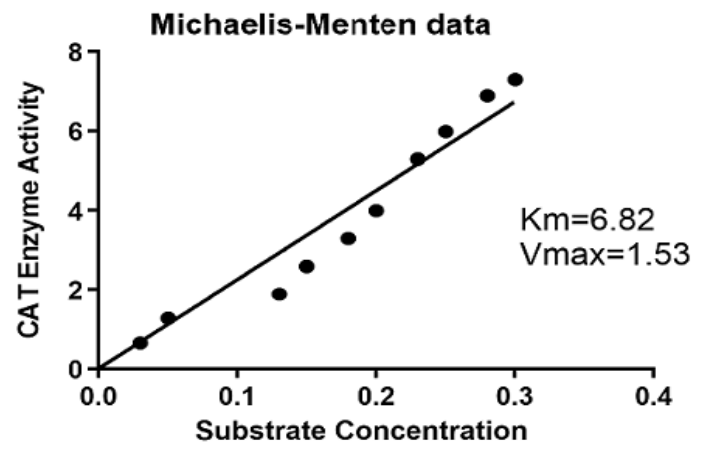

Figure 4. Km and Vmax graph for purified liver CAT from control $O$. niloticus.

$\mathrm{Km}$ value was noted $6.82 \mathrm{mM} \mathrm{H}_{2} \mathrm{O}_{2} \mathrm{~mL}^{-1}$ and $1.71 \mathrm{mM} \mathrm{H}_{2} \mathrm{O}_{2}$ $\mathrm{mL}^{-1}$ for control and $\mathrm{Pb}+\mathrm{Cd}$ metal mixture stressed $O$. niloticus, respectively (Fig. 4 and 5).

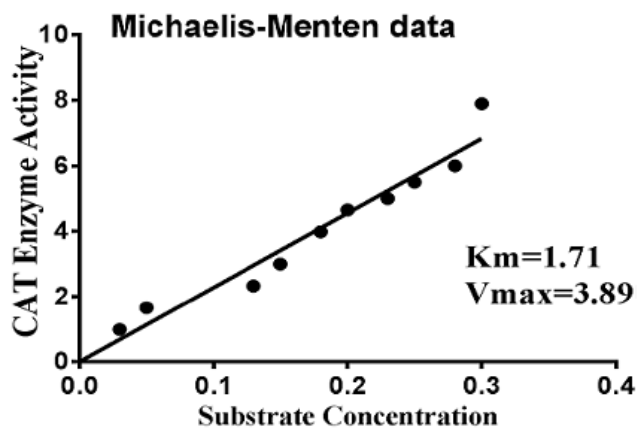

Figure 5. Km and Vmax graph for purified liver CAT from metal mixture stressed $O$. niloticus. 


\section{DISCUSSION}

The present study was performed with an objective to measure the liver catalase activity after its purification both from binary metal mixture stressed and control Oreochromis niloticus.

The results of present study showed lower CAT activity in metal mixture stressed $O$. niloticus liver compared to control $O$. niloticus. Statistical analysis revealed significant difference between control and metal mixture treated $O$. niloticus liver CAT activity. Lower CAT activity in the metal mixture stressed $O$. niloticus liver are according to the findings of Otto and Moon (1996) who studied antioxidant response in different tissues of brown bullhead from relatively polluted and non-polluted systems; McFarland et al. (1999) who studied oxidative stress and genotoxicity in livers of field collected Ameiurus nebulosus; Romeo et al. (2000) in sea bass; Rashed (2001) in O. niloticus; Ruas et al. (2008) in cichlid fishes; Pascoli et al. (2011) in Zosterisessor ophiocephalus and Faheem et al. (2012) in O. niloticus.

Metal mixture exposed fish CAT specific activity was recorded lower than that of control fish. Statistical analysis showed significant difference among control and metal treated $O$. niloticus regarding liver CAT specific activity. It is observed that activity and specific activity are antagonistic to each other in purification of enzyme. Inferences further indicated that after each step of purification, activity decreased and specific activity increased from crude extract to gel filtration chromatography and observed according to Dash and Philips (2012) in Hydra vulgaris and Al-Bar (2012) in Camelus dromedarius.

Yield or percent recovery of enzyme decreases gradually after each and every purification step and specific enzyme enrichment or fold purification increases after each step of purification. Percent recovery of an enzyme is the yield or recovery achieved after at any purification step. Yield of enzyme is gradually decreases during purification because only specific enzyme is going to be purify and other proteins (enzymes) not. So, the protein contents (enzyme yield) decreases gradually. Fold purification measured how many folds an enzyme purified or how many times an enzyme purified after each and every step of purification. Increasing in fold purification of liver CAT was observed at every step in this study because CAT contents increases due to purification. Percent recovery and fold purification inferences of present study are according to findings of Sarwar (2013) in Ctenopharyngodon idellus and Akram (2014) in Catla catla. Optimum $\mathrm{pH}$ of CAT enzyme purified from liver of both control and metal stressed $O$. niloticus was found 7. Statistical analysis also indicated that there is a significant difference in the activity of purified liver catalase enzyme at different $\mathrm{pH}$ within treatment beside between treatments. The optimum $\mathrm{pH}$ results obtained in this research work was found similar with the findings of work performed by Ito and Akuzawa (1983) in bovine milk; Al-Bar (2012) in Camelus dromedaries; Sarwar (2013) in Ctenopharyngodon idellus; Tariq (2013) in Cirrhinus mrigala and Akram (2014) in Catla catla. Temperature at which liver CAT purified from both control and metal mixture stressed $O$. niloticus showed highest activity was noted $25^{\circ} \mathrm{C}$ although purified CAT showed broad range of activity at different temperatures. The optimum temperature inferences of this study was found similar with Sarwar (2013) in Ctenopharyngodon idellus; Tariq (2013) in Cirrhinus mrigala and Akram (2014) in Catla catla. $\mathrm{Km}$ value was noted $6.82 \mathrm{mM} \mathrm{H} \mathrm{O}_{2} / \mathrm{mL}$ and $1.71 \mathrm{mM} \mathrm{H}_{2} \mathrm{O}_{2} / \mathrm{mL}$ for control and metal stressed $O$. niloticus, respectively. Vmax value for control liver was measured about 1.53 and 3.89 for metal treated liver CAT. Low value of Vmax indicates CAT stronger ability to bind with $\mathrm{H}_{2} \mathrm{O}_{2}$ (Al-Bar, 2012).

Antioxidant enzymes, especially CAT and superoxide dismutase are affected in the presence of cadmium because it displaces copper and iron from these enzymes. Due to direct binding of cadmium with CAT active site, its enzymatic activity inhibited. Inhibition of CAT activity is related to the binding of heavy metal ions to thiol (-SH) groups of the enzyme. As a result ROS increased in number (Faheem et al. 2012).

Lead $(\mathrm{Pb})$ and cadmium $(\mathrm{Cd})$ are hazardous heavy metals that come naturally through erosion and manmade activities that he adopted for his own benefits such as pesticides. Cadmium (Cd) does not produce ROS directly. It influence thiol status of cell by altering Glutathione S-transferase level and also accelerates the level of metallothioneins in the liver. Both these changes become the reason of lipid peroxidation of plasma membrane. Cadmium then enters into mitochondrial electron transport chain and began to accumulate here. It donates electrons and results in superoxide radical production (Senthilkumaar et al. 2012).

In present research work, $O$. niloticus was selected as an experimental animal and metal mixture of lead and cadmium was used to study liver CAT response. It is suggested to use other aquatic organisms and organs for bio-monitoring studies. Consequences of the existing research work further reveals to measure other heavy metal mixture effects on antioxidant immune system in future.

Conclusion: On the basis of present study inferences, it is concluded that chronic $\mathrm{Pb}+\mathrm{Cd}$ metal mixture stress condition did not improve the yield of liver CAT but inhibited. The present study results further indicated that antioxidant enzymes present in fish could be used in heavy metal contamination detection in aquatic ecosystem because these enzymes are sensitive bio-indicators.

Acknowledgments: This research work was completed in Enzyme Biotechnology Lab. (EBL), Department of Biochemistry, University of Agriculture, Faisalabad, Pakistan 
under the technical guidance of Samreen Rasul (PhD Scholar) and my beloved elder brother Shakeel Ahmed who help me financially and spiritually.

\section{REFERENCES}

A.P.H.A. 1998. Standard Method for Examination of Water and Waste Water, $20^{\text {th }}$ Ed. American Public Health Association (APHA), New York, p.1193.

Al-Bar, O.A.M. 2012. Characterization of partially purified catalase from camel (Camelus dromedarius) liver. Afr. J. Biotechnol. 11:9633-9640.

Almeida, J.A., R.E. Barreto, E.L.B. Novelli, F.J. Castro and S.E. Moron. 2009. Oxidative stress biomarkers and aggressive behavior in fish exposed to aquatic cadmium contamination. Neotrop. Ichthyol. 7:103-108.

Akram, H. 2014. Purification and characterization of liver and kidney catalase enzyme in wild and farmed Catla catla. M.Phil. Thesis, Department of Zoology and Fisheries, University of Agriculture, Faisalabad, Pakistan.

Borkovic, S.S., J.S. Saponjic, S.Z. Pavlovic, D.P. Blagojevic, S.M. Milosevic, T.B. Kovacevic, R.M. Radojicic, M.B. Spasic, R.V. Zikic and Z.S. Saicic. 2005. The activity of antioxidant defense enzymes in mussels (Mytilus galloprovincialis) from the Adriatic Sea. Comp. Biochem. Physiol. 141:366-374.

Chance, M. and A.C. Mehaly. 1977. Assay of catalase and peroxidase. Methods Enzymol. 2:764-817.

Dash, B. and T.D. Phillips. 2012. Molecular characterization of a catalase from Hydra vulgaris. Gene. 501:144-152.

Dunford, H.B. and J.S. Stillman. 1976. On the function and mechanism of action of peroxidases. Coord. Chem. Rev. 19:187-251.

Faheem, M., A.Q.K. Sulehria, M. Tariq, I. Khadija, A. Fiaz and M. Saeed. 2012. Effect of sub-lethal dose of cadmium chloride on biochemical profile and catalase activity in fresh water fish Oreochromis niloticus. Biologia Pak. 58:73-78.

Gornall, A.G., C.S. Bardwill and M.M. David. 1949. Determination of serum proteins by means of biuret reaction. J. Biol. Chem. 177:751-766.

Halliwell, B. and J.M.C. Gutteridge. 2001. Free Radicals in Biology and Medicine, $4^{\text {th }}$ Ed. Oxford University Press, Oxford, p.346.

Hermis-Lima, M. 2004. Oxygen in biology and biochemistry: Role of free radicals. In: K.B. Storey (ed.), Functional Metabolism: Regulation and Adaptation, $2^{\text {nd }}$ Ed. WileyLiss, Hoboken, pp.319-368.

Huang, H.R., Z.J. Chen, S. Kunes, G.D. Chang and T. Maniatis. 2010. Endocytic pathway is required for Drosophila Toll innate immune signaling. Proc. Natl. Acad. Sci. 107:8322-8327.
Ito, O. and R. Akuzawa. 1983. Purification, crystallization, and properties of bovine milk catalase. J. Dairy Sci. 66:967.

Kono, Y. and I. Fridovich. 1982. Superoxide radical inhibits catalase. J. Biol. Chem. 257:5751-5754.

Kralova, B. 1999. Electrophoretic methods for the isolation and characterization of enzymes: A review. Anal. Chem. Acta. 383:109-117.

Liu, M.Q., Y.J.R.F. Jiang, F.S. Zhang, S.P. McGrath and F.J. Zhao. 2007. Does cadmium play a physiological role in the hyper accumulator Thlaspi caerulescens? Chemosphere 71:1276-1283.

Masood, S., R.Z. Abbas, Z. Iqbal, M.K. Mansoor, Z.U.D. Sindhu, M.A. Zia and J.A. Khan. 2013. Role of natural antioxidants for the control of coccidiosis in poultry. Pak. Vet. J. 33:401-407.

McFarland, V.A., L.S. Inouye, C.H. Lutz, A.S. Jarvis, J.U. Larke and D.D. McCant. 1999. Biomarkers of oxidative stress and genotoxicity in livers of field collected brown bullhead Ameiurus nebulosus. Arch. Environ. Contam. Toxicol. 37:236-241.

Nakamura, K., M. Watanabe, Y. Sasaki and T. Ikeda. 2000. Purification and characterization of liver catalase in acatalasemic beagle dog: comparison with normal dog liver catalase. Int. J. Biochem. Cell Biol. 32:89-98.

Nanda, S. 1993. The environmental impact of a chloro-alkali factory in a river basin in Eastern India. Environment 13:121-124.

Naz, S., M. Javed, S. Hayat, S. Abdullah, M. Bilal and T. Shaukat. 2008. Long term effect of lead $(\mathrm{Pb})$ toxicity on the growth performance, nitrogen conversion ratio and yields of major carps. Pak. J. Agri. Sci. 45:53-58.

Nishida, Y. 2011. The chemical process of oxidative stress by copper (II) and iron (III) ions in several neurodegenerative disorders. J. Chem. 142:375-384.

Otto, D.M.D. and T.W. Moon. 1996. Phase I and II enzymes and antioxidant response in different tissues of brown bullhead from relatively polluted and non-polluted systems. Arch. Environ. Contam. Toxicol. 31:141-147.

Pascoli, F., E. Negratoa, A.D. Giancamillob, D. Bertottoa, C. Domeneghinib, C. Simontacchia, F. Mutinellic and G. Radaelli. 2011. Evaluation of oxidative stress biomarkers in Zosterisessor ophiocephalus from the Venice Lagoon, Italy. Aquat. Toxicol. 101:512-520.

Pavlovic, V.N., M.A. Ehrmann, M.G. Gaenzle and R.F. Vogel. 2005. Functional characterization of the proteolytic system of Cactobacillus sanfranciscensis DSM 20451 T. App. Microbiol. 71:6260-6266.

Radovanovic, T.B., S.S.B. Mitic, B.R. Perendija, S.G. Despotovic, S.Z. Pavlovic, P.D. Cakic and Z.S. Saicic. 2010. Superoxide dismutase and catalase activities in the liver and muscle of barbel (Barbus barbus) and its intestinal parasite (Pomphoryinchus laevis) from the danube river, Serbia. Arch. Biol. Sci. 62:97-105. 
Rashed, M.N. 2001. Cadmium and lead levels in fish (Oreochromis niloticus) tissues as biological indicator for lake water pollution. Environ. Monit. Assess. 68:75-89.

Romeo, M., M. Bennani, M.G. Barelli, M. Lafaurie and J.P. Girard. 2000. Cadmium and copper display different response towards oxidative stress in the kidney of the sea bass Dicentrarchus labrax. Aquat. Toxicol. 48:185-194.

Ruas, C.B.G., C.D. Carvalho, H.S.S. Araujo, E.L.G. Espinodla and M.N. Fernandes. 2008. Oxidative stress biomarkers of exposure in the blood of cichlid species from a metal contaminated river. Ecotoxicol. Environ. Saf. 71:86-93.

Sarwar, U. 2013. Purification and partial characterization of liver catalase enzyme from control and $\mathrm{Pb}+\mathrm{Cd}$ metal mixture stressed grass carp, Ctenopharyngodon idellus. M.Sc. Thesis, Department of Zoology and Fisheries, University of Agriculture, Faisalabad, Pakistan.

Schisler, N.J. and S.M. Singh. 1987. Inheritance and expression of tissue-specific catalase activity during development and aging in mice. Genome 29:748-760.

Senthilkumaar, P., S. Eswari, K. Velmurugan and S. Sarojini. 2012. Independent toxic effects of metallic compounds on Indian major carps. Ind. J. Sci. Technol. 5:3142-3149.
Sevcikova, M., H. Modra, A. Slaninova and Z. Svobodova, 2011. Metals as a cause of oxidative stress in fish: A review. Vet. Med. 56: 537-546.

Steel, R.G.D., J.H. Torrie and D. Dickey. 1997. Principles and Procedure of Statistics: A Biometrical Approach, $3^{\text {rd }}$ Ed. McGraw Hill Book Co. Inc., New York, pp.352-358.

Stohs, S.J. and D. Bagchi. 1995. Oxidative mechanisms in the toxicity of metal ions. Free Rad. Biol. Med. 18:321-336.

Tariq, M. 2013. Studies on the characterization of liver catalase in copper exposed Cirrhina mrigala. M.Sc. Thesis, Department of Zoology and Fisheries, University of Agriculture, Faisalabad, Pakistan.

Umbreen, H., M.A. Zia and S. Rasul. 2014. Kinetic characterization of glucose aerodehydrognase from Aspergillus niger EMS-150-F after optimizing the dose of mutagen for enhanced production of enzyme. Braz. J. Microbiol. 44:1105-1112.

Valko, M., C.J. Rhodes, J. Moncola, M. Lzakovic and M. Mazura. 2006. Free radicals, metals and antioxidants in oxidative stress-induced cancer. Biol-C Int. 160:1-40.

Zeng, H.W., Y.J. Cai., X.R. Liao, F. Zhang and D.B. Zhang. 2010. Production, characterization, cloning, and sequence analysis of mono functional catalase from Serratia marcescens SYBC08. J. Basic Microbiol. 50:1-10. 